\title{
MONUMENTAL BRASS OF THE REGENT MORAY.
}

George Seton, Esq., F.S.A. Scot., exhibited and presented to the Society a rubbing of the Brass of the Regent Moray, removed from St Giles' Church, Edinburgh, on the demolition of his tomb, during the repairs of the church in 1829 . Calderwood furnishes the following notice of "the Buriall of the Good Regent :"-" Upon Tuisday the 14th of Februar, [1569-70], the Regent's corps was careid from the Abbey of Halyrudhous to the Great Kirk of Edinburgh, and was bureid in the South ile. Mr Knox made a Sermon before the buriall, upon these words, 'Blessed are these that dee in the Lord.' Manie of the nobilitie were present. He moved three thowsand persons to shed teares for the losse of suche a good and godlie Governour. This epitaph following, made by $M r$ George Buchanan, was engraven in brasse, and set above his tombe:

[23 IANVARII 1569.]

IACOBO STOVARTO, MORAYIA COMITI, SCOTIE PROREGI;

VIRO, ETATIS SU $\mathscr{R}$, LONGE OPTIMO: AB INIMIOIS,

OMNIS MEMORIE DETERRIMIS, EX INSIDIIS EXTINCTO,

CEU FATRI COMMVNI, PATRIA MERENS POSVIT.".

The inscription is surmounted with the Regent's Arms couche, and the motto, SALUS PER CHRISTUM ; and on either side are the figures of Religion and Justice, 
with the mottoes;-IIETAS SINE viNDICE LUGET, and JUS EXanMatum Es?. The brass was inserted in an ornamental stone monument, which formed one of the most interesting adornments of the church, until its barbarous demolition in 1829 ; and it was a common occurrence, until a comparatively recent period, to assign it as the place of meeting, when any special contract was to be entered into, and also to make bills payable at "the Good Regent's tomb."

Repcated efforts having been made by the Society to procure the restoration of this national monument, it was now resolved to prepare a memorial to the Lord Provost and Magistrates, urging on them the duty of having the Brass, which has been removed to Donibrissle House, reclaimed, and the monument replaced on its original site in the south transept of St Giles' Church. 